\title{
EFEKTIVITAS FILTRAT BUAH MAHKOTA DEWA (Phaleria macro) SEBAGAI BIOINSEKTISIDA LARVA ULAT POLONG (Maruca testulalis) PADA TUMBUHAN KACANG PANJANG (Vigna unguiculata)
}

\author{
Devita Hardiyanti ${ }^{*}$, Sigit Prafiadi ${ }^{2}$, Revisika $^{3}$ \\ 1,2STKIP Muhammadiyah Manokwari, Jl. Trikora Rendani, Anday, Arfai, Papua Barat, 98312, \\ Indonesia \\ *Corresponding author, e-mail: devita011990@gmail.com
}

\begin{abstract}
This study aims to determine the effectiveness of the fruit filtrate of the Phaleria macro as bioinsecticide for the larvae of Maruca testulalis in long bean plants Vigna unguiculata. This research was conducted at the Integrated Science Laboratory of STKIP Muhammadiyah Manokwari in June 2019. The population used in this study was 150 larvae of Maruca testulalis. 7 treatment groups were consisting of 4 replications. The P0 treatment group was given $0.1 \mathrm{ml}$ of reagent solution, then for treatment P1, P2, P3, P4, $\mathrm{P} 5$, and $\mathrm{P} 6$ each was given the filtrate from the Phaleria macro with a concentration of $20 \%, 30 \%, 40 \%, 50 \%, 60 \%, 70 \%$. The results of data analysis using the Kruskal-Wallis test $5.708<12.591$ so that there was no effect of the bioinsecticide of the crown of gods on the larvae of Phaleria macro these results are influenced by the dose concentration that is not quite right. However, if it is seen from the results of the research data, it can be seen that there is an effect of giving the Phaleria macro fruit filtrate on the mortality of Maruca testulalis larvae. This effect is due to the presence of saponin compounds found in the Phaleria macro.
\end{abstract}

Keywords: Effectiveness, Bioinsecticide, Vigna unguiculata, Mortality, Maruca testulalis

\section{PENDAHULUAN}

Kacang panjang (Vigna unguiculata) merupakan salah satu tanaman sayuran sebagai sumber vitamin dan mineral. Fungsinya sebagai pengatur metabolisme tubuh, meningkatkan kecerdasan dan ketahanan tubuh memperlancar proses pencernaan karena kandungan seratnya yang tinggi (Zaevie et al., 2014). Tanaman tersebut tumbuh di seluruh wilayah tropik dan subtropik (Lingga, 2010). Kacang Panjang banyak ditanam oleh para petani di berbagai negara pada umumnya dan di Indonesia pada khususnya (Yusnita, 2014). Kacang panjang dalam proses perkembangannya mempunyai beberapa faktor yang mempengaruhi dalam penanaman dan pertumbuhannya diantaranya kontur tanah, suhu kelembapan dan hama. Beberapa hama yang menyerang tanaman kacang panjang antara lain, Lalat Bibit Kacang (Ophiomyia phaseolitryon), Ulat Grayak (Spodoptera litura), Kutu Daun (Aphis craccivora), Ulat Penggerek Polong (Maruca testualis), dan Kutu Kebul (Bemicia tabaci) (Rukmana, 2014). Ulat penggerek polong menyerang bagian bunga sehingga bunga tampak lubang. Serangan pada bagian bunga dan polong ini berpengaruh langsung terhadap produksi kacang panjang. 
Mahkota dewa (Phaleria macrocarpa) merupakan salah satu jenis tanaman obat yang sebagian besar dikonsumsi masyarakat Indonesia. Selama ini masyarakat Indonesia memanfaatkan kulit mahkota dewa sebagai bahan baku obat guna menyembuhkan berbagai macam penyakit. Biji mahkota dewa dapat dimanfaatkan sebagai bioinsektisida dan sebagai bahan obat obatan. Kandungan biji mahkota dewa alkaloid 0,55\%; saponin 20,4\%; polifend 0,23\% dan flavonoid 0,44\%. Zat axytosin dan sintosinon yang merangsang kerja otot rahim untuk mempermudah proses melahirkan selama persalinan dan saponin yang menghasilkan zat racun (Naria, 2005).

Untuk meningkatkan produksi tanaman kacang panjang dan mengurangi serangan dari hama penggerek ulat polong dapat memanfaatkan filtrat dari buah mahkota dewa yang dijadikan bioinsektisida. Kandungan saponin pada buah mahkota dewa diprediksi mampu mengatasi permasalahan hama penggerek ulat polong. Oleh sebab itu perlu dilakukan kegiatan ilmiah untuk melihat efektivitas filtrat buah mahkota dewa (Phaleria macro) sebagai bioinsektisida larva ulat polong (Maruca testulalis) pada tumbuhan kacang panjang (Vigna unguiculata).

\section{METODE}

Penelitian ini dilaksanakan di Laboratorium IPA Terpadu STKIP Muhammadiyah Manokwari pada bulan Juni, 2019. Populasi dalam penelitian ini adalah 150 larva ulat polong (Maruca testulalis). Pembuatan filtrat buah mahkota dewa dilakuakan dengan cara menghaluskan 3 gram buah mahkota dewa yang ditambahkan dengan aqudes dengan menggunakan blender. Selanjutnya dipanaskan dengan menggunakan kompor listrik dengan suhu $80^{\circ} \mathrm{C}$ sampai volume menjadi setengah bagian. Terdapat 7 kelompok perlakuan yang terdiri dari 4 kali ulangan. Kelompok perlakuan $\mathrm{P0}$ diberikan 0,1 ml larutan regent, selanjutnya untuk perlakuan P1, P2, P3, P4, P5, dan P6 masing-masing diberikan filtrat dari mahkota dewa dengan konsentrasi secara berturutan 20\%, 30\%, 40\%, 50\% dan 60\%. Pemberian perlakuan dilakukan dengan cara disemprot dengan menggunakan sprayer sebanyak 4 kali dalam satu hari, dengan melihat kematian sampel pada 3 kali 24 jam. Larva dikatakan mati jika tidak ada lagi respon dan apabila disentuh tidak bergerak, posisi tubuh dalam keadaan kaku atau tidak berubah.

Data yang terkumpul dianalisis dengan menggunakan statistik paramaterik untuk melihat pengaruh filtrat buah mahkota dewa terhadap mortalitas ulat polong, dengan terlebih dahulu dilakukan uji prasyarat untuk melihat data berdistribusi normal dan homogen. Jika tidak memenuhi syarat tersebut maka dilanjutkan dengan menggunakan uji nonparametrik (Sugiyono, 2013).

\section{HASIL DAN PEMBAHASAN}

Hasil analisis uji prasyarat diperoleh data hasil penelitian berdistribusi normal, namun tidak bersifat homogen maka analisis dilanjutkan dengan uji nonparametrik (Kruskal-Wallis). Hasil perhitungan Kruskal-Wallis 5,708< 12,591, sehingga tidak ada pengaruh bioinsektisida mahkota dewa terhadap larva ulat polong. Hasil tersebut dipengaruhi oleh kosentrasi dosis yang kurang tepat. Namun bila dilihat pada hasil penelitian tingkat mortalitas ulat polong pada konsentrasi $20 \%$ total larva ulat polong yang mati mencapai $15 \%$, untuk Konsentrasi $30 \%$ total larva ulat polong yang mati mencapai $10 \%$ untuk, konsentrasi $40 \%$ total ulat polong yang 
mati mencapai $25 \%$ untuk, konsentrasi $50 \%$ total ulat polong yang mati mencapai $25 \%$ untuk konsentrasi $60 \%$ total larva ulat polong yang mati mencapai $30 \%$, untuk konsentrasi $70 \%$ total larva ulat yang mati mencapai 30\%. Filtrat dari buah mahkota dewa yang mempengaruhi mortalitas ulat polong dikarenakan adanya senyawa saponin yang terkandung di dalam buah mahkota dewa (Haditomo, 2010).

Serangan ulat polong pada tanaman kacang panjang menyebabkan rendahnya produktivitas tanaman kacang panjang. Berdasarkan hasil identifikasi terhadap 9 jenis serangga hama pemakan polong, ulat polong (Maruca testulalis) merupakan salah satu jenis hama pemakan polong sangat berbahaya. Gagal panen akibat serangan hama tersebut dapat mencapai $80 \%$. Usaha pengendalian hama ditingkat petani hingga kini masih mengandalkan insektisida pabrikan, namun dipandang kurang efektif karena memerlukan biaya yang besar (Marwanto \& Suharsono, 2015). Ulat polong tersebar luas di Asia, Pasifik, dan Australia. Menurut Samsudin (2015), untuk mengendalikan hama tersebut petani umumnya menggunakan insektisida kimia yang intensif dengan frekuensi dan dosis tinggi, dan bahkan petani dalam menggunakan pestisida kadang-kadang menyalahi aturan, selain dosis yang digunakan melebihi takaran, petani juga sering mencampur beberapa jenis pestisida, dengan alasan untuk meningkatkan sifat toksik pada ulat polong. Tindakan yang demikian sebenarnya sangat merugikan, karena dapat menyebabkan semakin tinggi tingkat pencemaran pada lingkungan, menurunkan kesuburan tanah dan resistensi pada ulat polong itu sendiri (Afriyanto, 2016). Selain itu insektisida dapat menyebabkan dampak negatif seperti munculnya hama-hama baru, adanya residu insektisida yang berbahaya bagi manusia, hewan dan lingkungan (Sembel, 2010).

Senyawa Saponin yang terdapat pada filtrat buah mahkota dewa dapat menyebabkan penurunan kerja enzim pencernaan serta menghambat absorbsi makanan, selain itu senyawa saponin juga dapat menyebabkan degradasi kutikula yang menyebabkan cairan tubuh larva banyak yang keluar dan masuk melalui saluran pernafasan yang akan merusak tubuh (Kuddus et al., 2011). Saponin juga menggangu pertumbuhan larva dengan cara menghambat pengelupasan eksoskeleton larva sehingga tidak dapat berkembang ke fase selanjutnya, selain itu saponin dapat mengikat sterol yang berperan sebagai prekusor bagi hormone ekdison. Hormon ekdison adalah hormon yang memicu pergantian kulit. Selain merangsang pergantian kulit hormon ekdison juga mendorong perkembangan karakteristik perubahan ulat menjadi kupu-kupu, sehingga apa bila terdapat gangguan pada hormon ini, maka serangga akan terganggu proses perkembangannya, pada akhirnya akan mengakibatkan gangguan pada pertumbuhan dan perkembangan larva. Hasil penelitian ini sesuai dengan yang dilakukan Kristiana et al. (2015) yang menyatakan bahwa saponin mengandung gugus glikosil yang berperan sebagai gugus polar serta gugus steroid dan triterpenoid yang berfungsi sebagai gugus nonpolar senyawa saponin dapat menyebabkan kerusakan membran sel pada larva, sehingga larva yang terpapar saponin mengalami kerusakan membran sel dan selnya lisis. Akibat yang ditimbulkan kerusakan sel memungkinkan terjadinya perpindahan komponenkomponen penting dari dalam sel menuju keluar atau sebaliknya sehingga mempengaruhi metabolisme sel. Selain itu saponin memiliki fungsi sebagai insektisida dengan menurunkan tegangan permukaan selaput mukosa traktus digestivus yang menyebabkan dinding traktus digestivus ulat menjadi korosif (Alindatus et al., 2013). Membran sel termasuk dinding traktus digestivus yang rusak pada akhirnya dapat menyebabkan ulat mengelami kematian. Saponin mempunyai sifat berbusa dalam air, mempunyai sifat detergen yang baik dan beracun bagi 
binatang berdarah dingin, mempunyai aktivitas hemolysis, tidak beracun bagi binatang berdarah panas, mempunyai sifat anti eksodatis dan inflamatori (Danusulistyo, 2011) sehingga larva gagal molting atau berganti kulit, hasil ini sejalan dengan penelitian yang dilakukan Sa'diyah et al. (2013) yang menyebutkan bahwa adanya penghambatan perkembangan istar disebabkan karena mengalami gangguan pada saat ekdisis. Ekdisis atau ganti kulit diperlukan serangga tidak hanya untuk tumbuh melainkan juga untuk mencapai tahap dewasa sehingga dapat berkembang biak, senyawa yang mengganggu proses ekdisis salah satunya adalah saponin. Selain itu saponin memiliki kemampuan untuk merusak membrane (Yunita et al. 2009)

\section{SIMPULAN}

Hasil analisis statistik dengan menggunakan uji kruskal wallis diketahui bahwa tidak ada pengaruh pemberian filtrat buah mahkota dewa terhadap mortalitas larva ulat polong. Namun, jika dilihat dari data ada pengaruh pemberian filtrat buah mahkota dewa terhadap mortalitas larva ulat polong. Pengaruh tersebut dikarenakan adanya senyawa saponin yang terdapat pada buah mahkota dewa. Saponin mempunyai sifat berbusa dalam air, sifat detergen yang baik dan beracun bagi binatang berdarah dingin, mempunyai aktivitas hemolysis, dan memiliki sifat anti eksodatis dan inflamatori.

\section{REFERENSI}

Afriyanto. (2016). Kajian keracunan pestisida pada petani penyemprotan cabe di di Desa Candi Kecamatan Bandungan Kabupaten Semarang. (Thesis Ilmiah). Semarang: Program Pascasarjana Universitas Diponegoro.

Danusulistyo, M. 2011. Uji Larvasida Ekstrak Daun Lidah Buaya (Aloe vera L.) Terhadap Kematian Larva Nyamuk Anopheles aconitus. Skripsi Surakarta: Fakultas Ilmu Kesehatan Universitas Muhammadiyah.

Haditomo I. (2010). Efek larvasida ekstrak daun cengkeh (Syzgium Aromaticum) terhadap Aedes Aegypti L. Skripsi. Surakarta: Fakultas Kedokteran Universitas Sebelas Maret,.

Kristiana, I., D., Evie Ratnasari, T. H. (2015). Pengaruh Ekstrak Daun Bintaro (Cerbera odollam) terhadap Mortalitas Larva Nyamuk Aedes aegypti. Jurnal Lentera Bio, Vol. 3 (No. 4).

Kuddus, M. R. Rumi, F, dan Masud, M. M. (2011). Phytochemical Screening and a Antioxidant Activity Studies of Cebera odollam G. Journal of Pharma and Biosciences, 2 (1): 413-418.

Lingga, L. (2010). Cerdas Memilih Sayuran. Jakarta: Agromedia Putaka.

Marwanto dan Suharsono. (2015). Kajian aspek ketahanan beberapa genotip kedelai terhadap hama pengisap polong Riptortus linearis. Disertasi. Universitas Gadjah Mada Jogjakarta.

Naria, E. (2005). Insektisida Nabati untuk Rumah Tangga. Info Kesehatan Masyarakat Fakultas Kesehatan Masyarakat, 9(1), 28-32.

Rukmana, R. (2014). Sukses Budidaya Kacang Sayur Di Perkarangan dan Perkebunan. Yogyakarta: Lily Publisher.

Sa'diyah, N, A., Purwanti, K.I, dan Wijayanti, L. (2013). Pengaruh Ekstrak Daun Bintaro (Cerbera Odollam) Terhadap Perkembangan Ulat Grayak (Spodoptera litura). Jurnal Sains dan Seni ITS, 2(2), 111-115.

Sembel, T. D. (2010). Pengendalian Hayati: Hama-Hama Serangga Tropis dan Gulma Yogyakarta: Penerbit Andi. 
Sugiyono. (2013). Metode Penelitian Pendidikan. Bandung: Alfabeta.

Yunita, E., Suprapti, N., Hidayat, J. (2009). Pengaruh Ekstrak Daun Teklan (Eupatorium riparium) terhadap Mortalitas dan Perkembangan Larva Aedes aegepti. Jurnal Bioma, 11(1), 11-17.

Yusnita, R. (2014). Budidaya Kacang Panjang (Vigna unguiculata). Balai Penyuluhan Pertanian Perikanan dan Kehutanan (BP3K) Wilayah Jonggol.

Zaevie, Bastianus, Napitupulu Marisi, dan Astuti Puji. (2014). Respon Tanaman Kacang Panjang (Vigna sinensis) Terhadap Pemberian Pupuk NPK Pelangi dan Pupuk Organik Cair Nasa. Agrifor: Jurnal Ilmu Pertanian dan Kehutanan, 13(1), 19-32. DOI. https://doi.org/10.31293/af.v13i1.544. 